\title{
Individual and Environmental Correlates to Quality of Life in Park Users in Colombia
}

\author{
Diana Marina Camargo ${ }^{1, *}$, Paula Camila Ramírez ${ }^{1,2}$ (D) and Rogério César Fermino ${ }^{3,4}$ \\ 1 Research Group in Harmony, Movement and Life, Faculty of Physical Therapy, Universidad Industrial de \\ Santander, Bucaramanga 680002, Colombia; pcramire@uis.edu.co \\ 2 Research Group in Human Being, Culture and Movement, Universidad Santo Tomás, \\ Bucaramanga 680001, Colombia \\ 3 Research Group in Environment, Physical Activity and Health (GPAAFS), Postgraduate Program in Physical \\ Education, Federal University of Technology-Parana, Curitiba-PR 81310-900, Brazil; \\ rogeriofermino@utfpr.edu.br \\ 4 Research Group in Physical Activity and Quality of Life (GPAQ), Pontiff Catholic University of Parana, \\ Curitiba-PR 80215-901, Brazil \\ * Correspondence: dcamargo@uis.edu.co
}

Received: 18 August 2017; Accepted: 9 October 2017; Published: 19 October 2017

\begin{abstract}
Purpose: To explore individual and environmental correlates to quality of life (QoL) in park users in Colombia. Methods: A cross-sectional study with face-to-face interviews was conducted with 1392 park users from ten parks in Colombia. The survey included sociodemographic questions, health condition assessed with EuroQuol-5-Dimensions-5-Levels; in addition, questions about accessibility to the parks and perceptions about quality of infrastructure and green areas were asked. The Spanish version of the questionnaire EUROHIS-QOL-8 items was applied to assess QoL. Log-binomial regression models were applied for analyses. Results: Years of schooling, visits to the park with a companion, active use of the park, a maximum score for quality of trees and walking paths, and the perception of safety on the way to the park were positively associated with a better QoL $(p<0.05)$. Health conditions related to problems in the ability to perform activities of daily living and anxiety/depression showed negative associations. Conclusions: The present study contributes to the Latin American studies by providing information on how parks in an intermediate city may contribute to increased QoL of park users through safety in neighborhoods, social support, active use, and aesthetics, cleanliness, and care of green areas.
\end{abstract}

Keywords: quality of life; built environment; parks; recreational; health status

\section{Introduction}

In 1994, the World Health Organization (WHO) defined quality of life (QoL) as "individuals" perceptions of their position in life, in the context of the culture and value systems in which they live and in relation to their goals, expectations and concerns." [1]. This definition emphasizes a subjective and multi-dimensional concept because it includes several aspects such as health, psychological status, degree of independence, relationships with other people and with the environment, and spiritual or religious beliefs [1].

The growing level of urbanization worldwide makes the quality of cities and the built environment relevant in defining quality of life of their citizens [2]. In the environmental context, parks are identified as green spaces for collective use that act as regulators of environmental balance and represent an element of the natural heritage. They are designed for recreation, contemplation, and leisure of the citizens [3,4]. Parks also contribute to the conservation of natural resources and the ecosystem, reduce pollution, generate equality in inhabitants' development, contribute to the preservation of historical 
memory and create a sense of identity in the communities [3]. Besides, parks enhance the population's active lifestyles, mental health, and social cohesion while decreasing exposure to toxic conditions $[3,5]$. The availability of open spaces to people (such as appealing and safe parks) contributes to more active behavior in the population, social responsibility, and care of the public resources. It also improves coexistence, tolerance, health, and QoL of inhabitants [3,6].

The literature on associations between the use of parks and quality of life is scarce. From an ecological level, Larson [7] established a positive yet not significant relationship between park quantity (measured as the percentage of city area covered by public parks), park quality (measured as per capita spending on parks), and accessibility (measured as the overall percentage of a city's population within $\frac{1}{2}$ mile of parks). The study suggests that increasing these public spaces contribute to health and well-being in cities and positively impact urban quality of life.

Recently, Koramaz [8] proposed a conceptual model to understand the relationships between urban parks and health, physical activity, social relations, satisfaction with the neighborhood and their contributions to improve quality of the residential environment. The purpose of this model is to create a healthy society, especially in densely developed residential areas, giving clues into policies for increasing QoL through planning and design interventions for residential environments and urban parks [8].

Efforts to preserve open spaces and to create green infrastructure on a larger scale could be useful in making a positive impact on public health and the population's QoL [5,9]. For this reason, accessibility to these spaces in terms of proximity, walkability, travel time, safety, shared activities, and available leisure time among other factors should be a priority when deciding to invest in land conservation and parks $[10,11]$. Some studies assess the relationship between perceptions of natural environment infrastructure and one or more aspects of QoL. Positive associations were found for mental health in university students [12] and older adults [13]. Furthermore, a walk of $150 \mathrm{~min}$ or more during the previous week and the safety of the public space were positively associated with perceived health among senior citizens in North America [14].

In Colombia, two previous studies found the relevance of the built environment and parks for human well-being and quality of life. However, both highlight the need to expand the evidence in this regard, considering the role of some culturally distinctive features of people, the level of mass urbanization, and differences in the levels of connectivity, density, and land-use mix [15,16]. The aim of this study was to explore potential associations between individual and environmental correlates of QoL in Colombian park users.

\section{Materials and Methods}

\subsection{Location Of the Study and Ethical Aspects}

Bucaramanga is an intermediate city located on a plateau at 959 masl in the Cordillera Oriental (Easter Mountain Range) of the Colombian Andes. It has a municipal area of $165 \mathrm{~km}^{2}$ (approximately 64 square miles), a mean temperature of $23^{\circ} \mathrm{C}\left(73.4{ }^{\circ} \mathrm{F}\right)$, and 529,785 inhabitants. With a population density of $3130 \mathrm{hab} / \mathrm{km}^{2}$ and public space of $4.53 \mathrm{~m}^{2} / \mathrm{hab}, 52.4 \%$ of the homes in Bucaramanga are houses, $40.4 \%$ apartments, and the remaining $7.2 \%$ corresponds to other buildings. Socioeconomic status (SES) is determined by using the classification from the city Planning Department, which has six categories from 1 to 6 (poorest to richest), distributed as: 1-2 (29\%), 3-4 (60.1\%), 5-6 (10.9\%) [17].

Traditionally, Bucaramanga has been recognized as "The city of parks". From a total of 140 parks, there are 10 metropolitan parks ( $\geq 25 \mathrm{Ha}), 10$ zonal parks $(1.5-25 \mathrm{Ha}), 83$ local parks $(0.1-1.5 \mathrm{Ha})$, 37 pocket parks $(<0.1 \mathrm{Ha})$ and an index of green space of $2.51 \mathrm{~m}^{2} / \mathrm{hab}[18]$.

Like many Latin American cities, Bucaramanga's road and urban infrastructures have been growing, but with disorderly planning which makes the movement of vehicles and pedestrians difficult. In addition, the small area of the city on the plateau has caused priority to be given to the building of large-scale works for housing and mobilization, causing stress and discomfort for people. 
The Ethics Committee of the Universidad Industrial de Santander approved this project in the Act number 12 of 23 May 2014. All participants signed an informed consent form before being enrolled in the study.

\subsection{Design}

This is a cross-sectional study conducted in two zonal and eight local parks of the city. The selection criteria were: access (the community has free access to the park because of a non-existent or partial enclosure); operation and function (the park accomplishes the role described by the Land Use Plan (Plan de Ordenamiento Territorial) [17] for local parks (Free sports, games for children and adults, active and passive recreation with equipment, areas for free sports) and safety conditions during the inspection visit.

\subsection{Data Collection}

Parks were visited once in each selected day of the week (Tuesday, Wednesday, Thursday, Saturday, and Sunday) and users were surveyed face-to-face. Users were defined as people of both sexes, older than 12 years, who stayed in the park for at least $15 \mathrm{~min}$ they were selected by non-probabilistic sampling. Members of the fieldwork team interviewed them and each interview took between 12 and 15 min. Data collection was conducted between September and December 2015. Two observation periods were conducted from 6:00 am to noon and from 3:00 pm to 8:00 pm. The period between noon to 3:00 pm was not observed, based on cultural custom, when people go home for lunch and rest. Also, people usually take a nap before going back to work at two o'clock in the afternoon, reducing the number of park users; additionally, it is the time of the day with the highest temperatures.

\subsubsection{Explanatory Variables}

The following parameters were evaluated by a questionnaire designed for this study with 24 items: Sociodemographic variables (sex, age, length of residency in the neighborhood, city of residency, marital status, years of schooling, and number of children); Accessibility (visits to parks in the last month and year, visits to parks by proximity to home, frequency of visits, time in minutes from home to park, walk to get to the park, company for park visit, and active versus passive use). Active use was defined as walking, working out, or engaging in any kind of physical activity that involves movement, such as playing with a ball, jogging, walking a pet, walking with children/grandchildren, other, while passive use was sitting on a bench, just leaving the house, reading, chatting with friends, going for a drink, eating, other [19].

Park visitors were also asked nine items about their perception of some safety features and infrastructure of the park. This includes the condition of green areas, trees, and paths for walking and jogging on a scale from 1 (very low) to 5 (excellent), with the absence of the feature scored as zero.

Self-perception of health status was measured using the Spanish version of the EuroQol-5 Dimensions-5 Levels (EQ-5D-5L) questionnaire [20], a standardized measure of health status developed by the EuroQol Group in order to provide a simple, generic measure of health for clinical and economic appraisal. It includes five dimensions: mobility, self-care, usual activities, pain/discomfort, and anxiety/depression. Each attribute was scored on a 5-point ordinal scale, ranging from zero (0): "I have no problems ... , I have no pain ... , I am not anxious ... ", to four (4): "I am unable to ... , I have extreme pain ... ., I am extremely anxious ... ". A visual numeric scale $(0-100 \mathrm{~mm})$ with endpoints labeled with descriptive sentences, from "the worst health you can imagine" to "the best health you can imagine," is also included.

\subsubsection{Outcome Variable}

The QoL was measured using EUROHIS-QOL 8 questionnaire [21]. It is composed of eight items (overall QoL, general health, energy, daily life activities, self-esteem, relationships, finances, and household). The overall QoL score is formed by a simple summation of scores on the eight items, with higher scores indicating better QoL. All answer scales have a 5-point response format on a Likert 
scale, ranging from 'not at all' to 'completely'. The use of this questionnaire was approved by the World Health Organization.

A pilot test was done with 30 park users to standardize the procedures and determine the clarity of the questionnaire. We evaluated the internal consistency of the EUROHIS-QOL-8 questionnaire (Cronbach's $\alpha$ coefficient $=0.83$ ) and the reliability for each item (Kappa 0.33-0.64), also the total score showed an Intraclass Correlation Coefficient of 0.69 (95\% CI, 0.44-0.84).

Based on responses from the 1392 park users, we applied a Rasch analysis to the questionnaire, which showed a good fit after recoding to the original scores from 12345 to 00012 . The reliability results were for items (1.0) and persons (0.77); separation index for items (15.5) and persons (1.85). The INFIT and OUTFIT ranges varied between $0.74-1.30$ and $0.73-1.25$, for items and persons respectively. The explained variance was $46.3 \%$ and the unexplained variance in the first contrast was $11.2 \%$. A differential item functioning was not detected for either sex, age, schooling or active use of the park. Finally, the output variable was generated from the measurement obtained by the Rasch Model, that did not show a normal distribution, so a dichotomous variable was created from the median value as the cut-off point for the multivariate analysis.

\subsection{Data Analysis}

The associations were assessed by applying simple and multiple log-binomial regression models, to estimate the prevalence ratios (PR) and their 95\% confidence intervals. The modeling process followed Greenland's recommendations [22]. Considering the cluster sampling of the park users in the 10 parks studied, simple and multiple log-binomial regression analyses were adjusted by sampling method. The analyses were done in STATA 14.1 (Stata Press, 4905 Lakeway Drive, College Station, TX, USA) at a $5 \%$ significance level.

\section{Results}

A total of 1392 users participated in the study (response rate of 95\%), median age 42 years (range: 12-86), 813 (58.4\%) women, 510 (36.6\%) married (Table 1).

Table 1. Socio-demographic characteristics of park users $(\mathrm{N}=1392)$.

\begin{tabular}{|c|c|c|c|}
\hline Variable & $\begin{array}{c}\text { Male N (\%) } \\
579(41.6)\end{array}$ & $\begin{array}{c}\text { Female N (\%) } \\
813(58.4)\end{array}$ & $\begin{array}{l}\text { Total N (\%) } \\
1392(100)\end{array}$ \\
\hline Age (years) Median (IQR) & $46(29-58)$ & $41(27-54)$ & $42(28-55)$ \\
\hline \multicolumn{4}{|l|}{ Age group $n(\%)$} \\
\hline $12-20$ & $35(6.6)$ & $50(6.8)$ & $85(6.7)$ \\
\hline $21-59$ & $368(70.0)$ & $572(77.9)$ & $940(74.6)$ \\
\hline$\geq 60$ & $123(23.4)$ & $112(15.3)$ & $235(18.6)$ \\
\hline \multicolumn{4}{|l|}{ Marital status $n(\%)$} \\
\hline Married & $227(39.2)$ & $283(34.8)$ & $510(36.6)$ \\
\hline Single & $190(32.8)$ & $246(30.3)$ & $436(31.3)$ \\
\hline Cohabitant & $113(19.5)$ & $158(19.4)$ & $271(19.5)$ \\
\hline Other & $49(8.5)$ & $126(15.5)$ & $175(12.6)$ \\
\hline \multicolumn{4}{|l|}{ City of residence $n(\%)$} \\
\hline Bucaramanga & $528(91.2)$ & $751(92.4)$ & $1279(91.9)$ \\
\hline Floridablanca & $28(4.8)$ & $32(3.9)$ & $60(4.3)$ \\
\hline Girón/Piedecuesta/Other & $23(4.0)$ & $30(3.7)$ & $53(3.8)$ \\
\hline Length of residency (years) in the neighborhood Median (IQR) & $10(3-23)$ & $7(2-20)$ & $8(2-20)$ \\
\hline \multicolumn{4}{|l|}{ Years of Schooling $n(\%)$} \\
\hline $1-6$ & $98(17.4)$ & $152(19.1)$ & $250(18.4)$ \\
\hline $7-9$ & $51(9.0)$ & $75(9.4)$ & $126(9.3)$ \\
\hline $10-12$ & $189(33.4)$ & $281(35.3)$ & $470(34.6)$ \\
\hline $13-14$ & $92(16.3)$ & $129(16.2)$ & $221(16.2)$ \\
\hline$\geq 15$ & $135(23.9)$ & $158(19.9)$ & $293(21.5)$ \\
\hline
\end{tabular}


Table 1. Cont.

\begin{tabular}{lccc}
\hline \multicolumn{1}{c}{ Variable } & Male N (\%) & Female N (\%) & Total N (\%) \\
$\mathbf{5 7 9}(\mathbf{4 1 . 6 )}$ & $\mathbf{8 1 3}(\mathbf{5 8 . 4 )}$ & $\mathbf{1 3 9 2}(\mathbf{1 0 0 )}$ \\
\hline $\begin{array}{l}\text { Children } \boldsymbol{n}(\%) \\
\text { Yes }\end{array}$ & $418(72.1)$ & $652(80.2)$ & $1070(76.9)$ \\
\hline Number of children $\boldsymbol{n}(\%)$ & & & \\
1 & $91(21.7)$ & $196(30.1)$ & $287(26.8)$ \\
2 & $142(34.0)$ & $224(34.4)$ & $366(34.2)$ \\
$\geq 3$ & $185(44.3)$ & $232(35.6)$ & $417(39.0)$ \\
\hline
\end{tabular}

Ninety four percent of people visited the park during the previous year and $58.8 \%$ with a companion; $59 \%$ declared an active use of the park (Table 2).

Table 2. Characteristics of the visit to the park by the park users $(\mathrm{N}=1392)$.

\begin{tabular}{lccc}
\hline Variable & $\begin{array}{c}\text { Men N (\%) } \\
\text { N: 579 }\end{array}$ & $\begin{array}{c}\text { Women N } \\
\text { (\%) N: 813 }\end{array}$ & $\begin{array}{c}\text { Total N (\%) } \\
\text { N: 1392 }\end{array}$ \\
\hline Visited parks within the past month (YES) & $525(90.7)$ & $728(89.5)$ & $1253(90.0)$ \\
Visited parks within the past year (YES) & $554(95.7)$ & $755(92.9)$ & $1309(94.0)$ \\
Visited parks because it is close to home & $414(71.5)$ & $596(73.3)$ & $1010(72.6)$ \\
Visited the park two or more times during a regular week & $442(76.3)$ & $590(72.6)$ & $1032(74.1)$ \\
Time (minutes) from home to park Median (IQR) & $7(5-15)$ & $10(5-15)$ & $10(5-15)$ \\
Walking as transport to park n (\%) & $412(71.0)$ & $619(76.0)$ & $1031(74.1)$ \\
Usually visits the park with a companion & $268(46.3)$ & $551(67.8)$ & $819(58.8)$ \\
Park use & & & \\
Active & $378(65.3)$ & $444(54.6)$ & $822(59.0)$ \\
Passive & $201(34.7)$ & $369(43.4)$ & $570(41.0)$ \\
\hline
\end{tabular}

In perception of safety, $28.5 \%$ considered dangerous going to the park, $69.5 \%$ always feel safe on the way to the park, and $71.5 \%$ feel safe within the park.

The scores of the global condition for park infrastructure features are shown in Table 3. The higher scores by park users were registered for trees and walking paths with $43.1 \%$ and $35.6 \%$, respectively.

Table 3. Perceptions related with global condition of park infrastructure features $(\mathrm{N}=1392)$.

\begin{tabular}{lcccccc}
\hline \multirow{2}{*}{\multicolumn{1}{c}{ Variable }} & \multicolumn{5}{c}{ Score $^{\mathbf{a}}$} \\
\cline { 2 - 7 } & $\mathbf{0 ~ N ~ ( \% )}$ & $\mathbf{1 ~ N ~ ( \% )}$ & $\mathbf{2 ~ N ~ ( \% )}$ & $\mathbf{3 ~ N ~ ( \% )}$ & $\mathbf{4 ~ N ~ ( \% ) ~}$ & $\mathbf{5 ~ N ~ ( \% ) ~}$ \\
\hline Overall cleanliness and hygiene & $1(0.07)$ & $74(5.3)$ & $138(9.9)$ & $367(26.4)$ & $467(33.6)$ & $344(24.7)$ \\
Meadows and green areas & $27(1.9)$ & $236(17.0)$ & $268(19.3)$ & $350(25.2)$ & $299(21.5)$ & $211(15.2)$ \\
Trees & $1(0.07)$ & $34(2.4)$ & $87(6.3)$ & $222(16.0)$ & $447(32.1)$ & $600(43.1)$ \\
Walking paths & $4(0.3)$ & $26(1.9)$ & $61(4.4)$ & $233(16.8)$ & $572(41.1)$ & $495(35.6)$ \\
Jogging trails & $207(14.9)$ & $24(1.7)$ & $61(4.4)$ & $226(16.3)$ & $495(35.6)$ & $378(27.2)$ \\
Bicycle routes & $1102(79.2)$ & $21(1.5)$ & $34(2.4)$ & $73(5.3)$ & $92(6.6)$ & $69(5.0)$ \\
\hline
\end{tabular}

a Score: 0: Absent/1: Very low/2: Low/3: Moderate/4: Good/5: Excellent.

Health status items (Table 4), reflect a good overall assessment of self-care and usual activities. However, the dimensions of pain, anxiety/depression, and mobility showed the lower prevalence in this category (75\%). Additionally, the visual numeric scale showed a median value of 90 (range 0-100). 
Table 4. Health status of the park users evaluated through the EQ5D-5L questionnaire $(\mathrm{N}=1392)$.

\begin{tabular}{lccccc}
\hline \multirow{2}{*}{ Dimension } & \multicolumn{5}{c}{ Score N (\%) } \\
\cline { 2 - 6 } & $\mathbf{0 ~ N ~ ( \% )}$ & $\mathbf{1 ~ N ~ ( \% )}$ & $\mathbf{2 ~ N ~ ( \% )}$ & $\mathbf{3 ~ N ~ ( \% )}$ & $\mathbf{4 ~ N ~ ( \% ) ~}$ \\
\hline Mobility $^{\mathrm{a}}$ & $1233(88.9)$ & $81(5.8)$ & $52(3.7)$ & $20(1.4)$ & $3(0.2)$ \\
Self-care $^{\mathrm{a}}$ & $1342(96.6)$ & $30(2.2)$ & $11(0.8)$ & $6(0.4)$ & $0(0)$ \\
Usual activities $^{\mathrm{a}}$ & $1322(95.2)$ & $1(3.0)$ & $19(1.4)$ & $6(0.4)$ & $0(0)$ \\
Pain/discomfort $^{\mathrm{b}}$ & $1041(75.0)$ & $167(12.0)$ & $125(9.0)$ & $52(3.7)$ & $4(0.3)$ \\
Anxiety/depression $^{\mathrm{c}}$ & $1215(87.5)$ & $121(8.7)$ & $39(2.8)$ & $12(0.9)$ & $2(0.1)$ \\
\hline
\end{tabular}

a Score: 0: I have no problems/4: I am unable. ${ }^{\mathrm{b}}$ Score: 0: I have no pain or discomfort/4: I have extreme pain or discomfort. ${ }^{c}$ Score: 0: I am not anxious or depressed/4: I am extremely anxious or depressed.

The scores for EUROHIS-QOL 8-items showed a high level of satisfaction (4 and 5) for all dimensions, except for having enough money for daily needs (Table 5); the overall QoL score registered a median value of 33 (range 13-40).

Table 5. Quality of life of the park users evaluated through EUROHIS-QOL 8-items.

\begin{tabular}{|c|c|c|c|c|c|}
\hline \multirow{2}{*}{ Dimension } & \multicolumn{5}{|c|}{ Score } \\
\hline & $1 \mathrm{~N}(\%)$ & 2 N (\%) & $3 \mathrm{~N}(\%)$ & 4 N (\%) & $5 \mathrm{~N}(\%)$ \\
\hline $\begin{array}{l}\text { How would you rate your quality } \\
\text { of life }^{\text {a }}\end{array}$ & $2(0.1)$ & $33(2.4)$ & $184(13.3)$ & $822(59.2)$ & $347(25.0)$ \\
\hline $\begin{array}{l}\text { How satisfied are you with } \\
\text { your health? }{ }^{b}\end{array}$ & $2(0.1)$ & $41(3.0)$ & 130 (9.3) & $774(55.8)$ & 441 (31.8) \\
\hline $\begin{array}{l}\text { Do you have enough energy for } \\
\text { everyday life? }{ }^{c}\end{array}$ & $1(0.3)$ & $35(2.5)$ & 175 (12.6) & $599(43.2)$ & $535(38.5)$ \\
\hline $\begin{array}{l}\text { How satisfied are you with your } \\
\text { ability to perform your daily } \\
\text { living activities? }{ }^{b}\end{array}$ & $2(0.1)$ & $25(1.8)$ & 107 (7.7) & $719(51.8)$ & 441 (31.8) \\
\hline $\begin{array}{l}\text { How satisfied are you with } \\
\text { yourself? } b\end{array}$ & $0(0.0)$ & $23(1.7)$ & $81(5.8)$ & 605 (43.6) & $679(48.9)$ \\
\hline $\begin{array}{l}\text { How satisfied are you with your } \\
\text { personal relationships? }{ }^{b}\end{array}$ & $6(0.4)$ & $29(2.1)$ & 138 (9.9) & $659(47.5)$ & $556(40.1)$ \\
\hline $\begin{array}{l}\text { Do you have enough money to } \\
\text { meet your needs? }{ }^{c}\end{array}$ & $18(1.3)$ & $112(8.1)$ & $591(42.6)$ & $447(32.2)$ & $220(15.8)$ \\
\hline $\begin{array}{l}\text { How satisfied are you with the } \\
\text { conditions of your living place? } b\end{array}$ & $9(0.6)$ & 77 (5.6) & $144(10.3)$ & 581 (41.9) & 577 (41.6) \\
\hline
\end{tabular}

a Score: 1: Very bad/5: Very good. ${ }^{\mathrm{b}}$ Score: 1: Very unsatisfied/5: Very satisfied. ${ }^{\mathrm{c}}$ Score: 1: Not at all/5: A lot.

Years of schooling, visiting the park with a companion, active use of the park, a maximum score (5) for the condition of trees and walking paths, and the perception of safety on the way from home to the park were positively associated with a better QoL (Table 6). Only health conditions related to problems in the ability to perform daily living activities and the expression of anxiety/depression showed negative associations. Sex, age, length of residency in the neighborhood, and frequency of park visits did not show significant associations in the simple regression analysis $(p>0.25)$ and were not included in the final model. 
Table 6. Associated factors to quality of life in park users $(\mathrm{N}=1357$, Link test $p$ : 0.18$)$.

\begin{tabular}{|c|c|c|c|c|}
\hline \multirow[t]{2}{*}{ Variable } & \multirow{2}{*}{$\begin{array}{c}\text { Simple Regresion } \\
\text { PR }^{\text {a }}\end{array}$} & \multirow[t]{2}{*}{$95 \% \mathrm{CI}$} & \multirow{2}{*}{$\begin{array}{c}\text { Multiple Regresion } \\
\text { PR }^{\text {a }}\end{array}$} & \multirow[t]{2}{*}{$95 \% \mathrm{CI}$} \\
\hline & & & & \\
\hline \multicolumn{5}{|l|}{ Years of schooling } \\
\hline $1-6$ & 1.0 & & 1.0 & \\
\hline 7-9 & 1.31 & $0.96-1.78$ & 1.25 & $0.96-1.62$ \\
\hline $10-12$ & 1.48 & $1.15-1.90$ & 1.37 & $1.09-1.71$ \\
\hline $13-14$ & 1.49 & $1.05-2.12$ & 1.36 & $0.96-1.92$ \\
\hline$\geq 15$ & 1.58 & $1.18-2.11$ & 1.51 & $1.16-1.97$ \\
\hline Visit to the park with a companion & 1.16 & $1.00-1.34$ & 1.12 & $1.01-1.25$ \\
\hline Active use of the park & 1.13 & $0.96-1.33$ & 1.14 & $1.00-1.30$ \\
\hline Tree conditions status (score $=5$ ) & 1.22 & $1.05-1.42$ & 1.20 & $1.07-1.34$ \\
\hline Walking paths conditions (score $=5$ ) & 1.33 & $1.10-1.61$ & 1.21 & $1.03-1.41$ \\
\hline $\begin{array}{l}\text { Perception of safety on the way } \\
\text { from home to the park (always) } \\
\text { Health status (EQ5D) }\end{array}$ & 1.26 & $1.10-1.44$ & 1.22 & $1.04-1.44$ \\
\hline \multicolumn{5}{|l|}{ Health status (EQ5D) } \\
\hline $\begin{array}{l}\text { Slight problems in walking to } \\
\text { unable to walk }(1-4)\end{array}$ & 0.19 & $0.07-0.50$ & 0.39 & $0.17-0.90$ \\
\hline $\begin{array}{l}\text { Slight to extreme } \\
\text { Anxiety/Depression (1-4) }\end{array}$ & 0.61 & $0.48-0.76$ & 0.69 & $0.54-0.86$ \\
\hline
\end{tabular}

\section{Discussion}

This is the first study in Colombia and Latin America that explores some individual and environmental correlates to perceived QoL in park users. Findings are supported in the theoretical model proposed by Koramaz [8] in which the interaction between subjective and objective personal and environmental characteristics perceived by persons related with urban parks, social relationships, health, and physical activity contribute to their QoL. From this point of view, it is a useful resource to guiding concerted interventions by authorities, planners, and users to improve their quality and services.

User characteristics found in this study are similar to those found in Brazil [23], where $63 \%$ of users were female; in the United States of America (USA) [24] and Canada [25] there were more men, $62 \%$ and $64 \%$, respectively. These differences could be attributed to the number of facilities and size of parks available for the community in North American countries. Furthermore, the weather conditions in cities like Bucaramanga and Recife, near to the equator, may also make a difference in the preferences of their inhabitants for park visits.

This study showed a prevalence higher than $90 \%$ for visits to parks during the past year and month, which may be explained by closeness to home (72.6\%), time from home to park (median $10 \mathrm{~min}$ ) and walking as transport to the park (74\%), and frequency of visit of more than once a week (74.1\%). Fifty-nine percent of people visited the park with a companion and the same prevalence was registered for active use of parks. Also, the positive perception of safety was reported by $70 \%$ of the users. These results could be explained by the theoretical model proposed by Bedimo-Rung et al. [3], Koramaz et al. [8], and Wang et al. [11] in which personal characteristics of the users, social support by friends and family and health condition, aggregated to physical characteristics of the environment like safety and aesthetics, could contribute to differential uses of parks and QoL of users.

The availability of local and pocket parks in Bucaramanga offer safe and nearby spaces to the residents of the neighborhood that, despite having a smaller area compared to those in the USA and Canada [24,25], has been identified as one of the main factors associated with their use. In Curitiba, $61 \%$ of people visited a park [26] and walking was the favorite activity of the users [27]. Also, each additional use per week of the natural environment reduced the risk of poor mental health by $6 \%$, underlining the importance of the natural environment, in which forests and parks seem to have a more beneficial effect [28]. 
There were no studies associating years of schooling and QoL in park users. However, it is possible to explain that education affects the quality of life of individuals in many ways. People with low schooling have fewer opportunities of high-paying jobs. Moreover, low-income neighborhoods are evident in its characteristics of safety, cleanliness, public services, and public spaces. These environmental characteristics could correlate in a negative way with their well-being and QoL [29].

Among the perceptions of environmental factors associated to better QoL, safety on the way to the park ( $\mathrm{PR}=1.17$ ), visiting the park with a companion ( $\mathrm{PR}=1.17)$, and highest scores for trees and walking paths ( $P R=1.25$ and 1.18, respectively) were significant. The effects of physical built environments like parks on some dimensions of QoL have been reported in several studies, at any age group.

Canadian adolescents reported increased emotional well-being due to the perception of neighborhood safety and decreased due to the perception of trash and abandoned houses [30]. For university students, the interference of the natural environment on their mental health is explained by their preferences for known environments, and they point to the benefit of mature trees and water sources which provide an opportunity for relaxing and reflecting off-campus [12]. For older adults, green and blue spaces are an important component of maintaining habits and QoL. Without a work routine, older adults need to devote time to activities that provide a daily routine and give them reasons to leave the house reducing boredom, isolation, and loneliness and giving their lives physical, spiritual, and social purposes, important dimensions of QoL [14].

The positive role of size, aesthetics, and quality of public and green spaces on QoL have been demonstrated in several studies. Van Den Berg [31] concluded that contact with nature in parks has a positive association with overall health, particularly for low-strata groups and the immigrant population, contributing to feelings of well-being and relaxation; Song [32] demonstrated by experimental design, that walking in parks compared to streets generates a better mood as well as less anxiety and fewer negative emotions; Grinde [33] established that aesthetics and nature are very important in generating a positive effect on the well-being and health of people, giving pleasure to the mind, stress relief, mental restoration and mood improvement in conscious or unconscious ways.

Therefore, environmental aspects are central to urban planning in developing countries, especially given the limited public and green space available, as well as the high level of urbanization in the coming years, which could reflect in detriment of air quality, physical activity, and health of citizens [34]. A few limitations of the study must be pointed out. First, this was a cross-sectional study, so no causal associations can be made; second, we assessed all research items through a face-to-face survey and only park users were surveyed, which could represent potential reporting and selection biases; third, this is an exploratory study that included only some variables potentially associated to QoL from the individual and environmental point of view of park users.

However De Jong et al. [35] showed correlations between 0.32 and 0.51 when comparing subjective versus objective measurements for assessing the green space of neighborhoods, which could support a potential control of a classification bias in the measurement performed via questionnaire versus objective measurements. In addition, conceptual models and observational studies support the associations found in this study.

\section{Conclusions}

The present study contributes to the Latin American studies by providing information on how the parks in an intermediate city may contribute to increased QoL of park users through safety in neighborhoods, social support, active use, aesthetics, cleanliness, and care of green areas. These findings must engage urban planners and decision makers to increase the quantity and quality of public space, planning programs, and policies to protect, create, and promote the natural environment as parks for citizens.

Acknowledgments: This study was funded by the Colombian Administrative Department of Science, Technology and Innovation-COLCIENCIAS (grant number 110265740960). 
Author Contributions: Each author contributed individually and significantly for the development of this manuscript. Diana Marina Camargo and Paula Camila Ramírez were responsible for the initial concept of the study, data collection, literature review, data analysis, writing, and reviewing the manuscript in all its stages. Rogério César Férmino participated in training, data collection, and writing of the manuscript. All authors approved the final version of the manuscript.

Conflicts of Interest: The authors declare no conflicts of interest.

\section{References}

1. Saxena, S.; Orley, J. Quality of life assessment: The World Health Organization perspective. Eur. Psychiatry 1997, 12, 263s-266s. [CrossRef]

2. UNO-HABITAT. World Cities Report 2016: Urbanization and Development_Emerging Futures. Available online: http:/ / wcr.unhabitat.org/main-report/ (accessed on 15 September 2017).

3. Bedimo-Rung, A.L.; Mowen, A.J.; Cohen, D.A. The significance of parks to physical activity and public health: A conceptual model. Am. J. Prev. Med. 2005, 28, 159-168. [CrossRef] [PubMed]

4. Koohsari, M.J.; Mavoa, S.; Villanueva, K.; Sugiyama, T.; Badland, H.; Kaczynski, A.T.; Owen, N.; Giles-Corti, B. Public open space, physical activity, urban design and public health: Concepts, methods and research agenda. Health Place 2015, 33, 75-82. [CrossRef] [PubMed]

5. Perdue, W.C.; Stone, L.A.; Gostin, L.O. The built environment and its relationship to the public's health: The legal framework. Am. J. Public Health 2003, 93, 1390-1394. [CrossRef] [PubMed]

6. Ward, C. Activity, exercise and the planning and design of outdoor spaces. J. Environ. Psychol. 2013, 34, 79-96. [CrossRef]

7. Larson, L.R.; Jennings, V.; Cloutier, S.A. Public parks and wellbeing in urban areas of the United States. PLoS ONE 2016, 11, e0153211. [CrossRef] [PubMed]

8. Koramaz, E.K.; Turkoglu, H. Measuring and understanding urban parks' contribution to Quality of Life in Istanbul. Soc. Indic. Res. 2017. [CrossRef]

9. Rydin, Y.; Bleahu, A.; Davies, M.; Dávila, J.D.; Friel, S.; De Grandis, G.; Groce, N.; Hallal, P.C.; Hamilton, I.; Howden-Chapman, P.; et al. Shaping cities for health: Complexity and the planning of urban environments in the 21st century. Lancet 2012, 379, 2079-2108. [CrossRef]

10. Power, A.; Davis, J.; Plant, P.; Kjellstrom, T. Strategic Review of Health Inequalities in England Post-2010. Task Group 4: The Built Environment and Health Inequalities. 2009. Available online: https:/ / core.ac.uk/ download/pdf/17288.pdf (accessed on 20 September 2017).

11. Wang, D.; Brown, G.; Liu, Y. The physical and non-physical factors that influence perceived access to urban parks. Landsc. Urban Plan. 2015, 13, 353-366. [CrossRef]

12. Windhorst, E.; Williams, A. "It's like a different world": Natural places, post-secondary students, and mental health. Health Place 2015, 34, 241-250. [CrossRef] [PubMed]

13. Kim, J.; Yamada, N.; Heo, J.; Han, A. Health benefits of serious involvement in leisure activities among older Korean adults. Int. J. Qual. Stud. Health Well-Being 2014, 9, 24616. [CrossRef] [PubMed]

14. Finlay, J.; Franke, T.; McKay, H.; Sims-Gould, J. Therapeutic landscapes and wellbeing in later life: Impacts of blue and green spaces for older adults. Health Place 2015, 34, 97-106. [CrossRef] [PubMed]

15. Parra, D.C.; Gómez, L.F.; Fleischer, N.L.; Pinzón, J.D. Built environment characteristics and perceived active park use among older adults: Results from a multilevel study in Bogota. Health Place 2010, 16, 1174-1181. [CrossRef] [PubMed]

16. Scopelliti, M.; Carrusb, G.; Adinolfic, C.; Suareze, G.; Colangeloc, G.; Lafortezzac, R.; Panno, A.; Sanesi, G. Staying in touch with nature and well-being in different income groups: The experience of urban parks in Bogotá. Landsc. Urban Plan. 2016, 148, 139-148. [CrossRef]

17. Alcaldía de Bucaramanga. Plan de Ordenamiento Territorial de Bucaramanga. Segunda Edición 2013-2027. Febrero de 2014. Available online: www.concejodebucaramanga.gov.co/planordenamientoterritorial/tomo2. pdf (accessed on 15 September 2017).

18. Alcaldía de Bucaramanga. Observatorio Metropolitano de Bucaramanga. Espacio Público y Verde Metropolitano. Available online: http://www.observatoriometropolitano.com.co/indicadores.aspx? idIndicador=1 (accessed on 15 September 2017). 
19. Walker, J.T.; Mowen, A.J.; Hendricks, W.W.; Kruger, J.; Morrow, J.R.; Bricker, K. Physical activity in the park setting (PA-PS) questionnaire: reliability in a California statewide sample. J. Phys. Act. Health 2009, 6 (Suppl. 1), S97-S104. [CrossRef] [PubMed]

20. Van Reenen, M.; Janssen, B. Version EQ-5D-5L. User Guide Basic Information on How to Use the EQ-5D-5L Instrument. Version 2.1. 2015. Available online: http://www.euroqol.org/fileadmin/user_upload/ Documenten/PDF/Folders_Flyers/EQ-5D-5L_UserGuide_2015.pdf (accessed on 16 September 2017).

21. Rocha, N.S.; Power, M.J.; Bushnell, D.M.; Fleck, M.P. The EUROHIS-QOL 8-item index: comparative psychometric properties to its parent WHOQOL-BREF. Value Health 2012, 15, 449-457. [CrossRef] [PubMed]

22. Greenland, S. Modeling and variable selection in epidemiologic analysis. Am. J. Public Health 1989, 79, 340-349. [CrossRef] [PubMed]

23. Hallal, P.C.; Reis, R.S.; Parra, D.C.; Hoehner, C.; Brownson, R.C.; Simões, E.J. Association between perceived environmental attributes and physical activity among adults in Recife, Brazil. J. Phys. Act. Health 2010, 7 (Suppl. 2), S213-S222. [CrossRef] [PubMed]

24. Cohen, D.A.; McKenzie, T.L.; Sehgal, A.; Williamson, S.; Golinelli, D.; Lurie, N. Contribution of public parks to physical activity. Am. J. Public Health 2007, 97, 509-514. [CrossRef] [PubMed]

25. Kaczynski, A.T.; Potwarka, L.R.; Saelens, B.E. Association of park size, distance, and features with physical activity in neighborhood parks. Am. J. Public Health 2008, 98, 1451-1456. [CrossRef] [PubMed]

26. Férmino, R.C.; Reis, R.S.; Hallal, P.C.; Kaczynski, A.T. Who are the users of urban parks? A study with adults from Curitiba, Brazil. J. Phys. Act. Health 2015, 12, 58-67. [PubMed]

27. Cohen, D.A.; Marsh, T.; Williamson, S.; Derose, K.P.; Martinez, H.; Setodji, C.; McKenzie, T.L. Parks and physical activity: Why are some parks used more than others? Prev. Med. 2010, 50 (Suppl. 1), S9-S12. [CrossRef] [PubMed]

28. Mitchell, R. Is physical activity in natural environments better for mental health than physical activity in other environments? Soc. Sci. Med. 2013, 91, 130-134. [CrossRef] [PubMed]

29. Quality of Life Indicators-Education, Eurostats. Statistics Explained. Available online: http:/ / ec.europa. eu/eurostat/statistics-explained/index.php/Quality_of_life_indicators_-_education\#Conclusions (accessed on 18 September 2017).

30. Huynh, Q.; Craig, W.; Janssen, I.; Pickett, W. Exposure to public natural space as a protective factor for emotional well-being among young people in Canada. BMC Public Health 2013, 13, 407. [CrossRef] [PubMed]

31. Van Den Berg, M.; Wendel-Vos, W.; Van Poppel, M.; Kemper, H.; Van Mechelena, W.; Maas, J. Health benefits of green spaces in the living environment: A systematic review of epidemiological studies. Urban For. Urban Green 2015, 14, 806-816. [CrossRef]

32. Song, C.; Ikei, H.; Igarashi, M.; Miwa, M.; Takagaki, M.; Miyazaki, Y. Physiological and psychological responses of young males during spring-time walks in urban parks. J. Physiol. Anthropol. 2014, 33, 8-15. [CrossRef] [PubMed]

33. Grinde, B.; Patil, G.G. Biophilia: does visual contact with nature impact on health and well-being? Int. J. Environ. Res. Public Health 2009, 6, 2332-2343. [CrossRef] [PubMed]

34. D'Alessandro, D.; Buffoli, M.; Capasso, L.; Fara, G.M.; Rebecchi, A.; Capolongo, S. Hygiene on built environment working group on healthy buildings of the Italian Society of Hygiene, Preventive Medicine and Public Health (SItI). Epidemiol. Prev. 2015, 39 (Suppl. 1), 8-13. [PubMed]

35. De Jong, K.; Albin, M.; Skärbäck, E.; Grahn, P.; Wadbro, J.; Merlo, J. Area-aggregated assessments of perceived environmental attributes may overcome single-source bias in studies of green environments and health: Results from a cross-sectional survey in southern Sweden. Environ. Health 2011, 10, 4. [CrossRef] [PubMed]

(C) 2017 by the authors. Licensee MDPI, Basel, Switzerland. This article is an open access article distributed under the terms and conditions of the Creative Commons Attribution (CC BY) license (http://creativecommons.org/licenses/by/4.0/). 